\title{
EVALUATION ON GREEN OPEN SPACE AS HEALTH PROMOTER WITH SALUTOGENIC APPROACH: CITY FOREST BSD I AS CASE STUDY
}

\author{
Ayu Larasati \\ Universitas Pelita Harapan, Lippo Karawaci \\ ayu.larasati@uph.edu \\ Rosdiana Pakpahan \\ Universitas Pelita Harapan, Lippo Karawaci \\ rosdiana.pakpahan@uph.edu
}

Received: 19 August 2019

Final Version Received: 12 November 2019

\begin{abstract}
Sedentary/passive behavior has increased the risk of non-communicable disease, which incites the need to encourage active activities in outdoor space. However, the green open space (GOS) amount has not yet achieved the minimum $30 \%$ of the total area, and the design quality as active activities promoter (health) has not yet had any design reference. Therefore, design evaluation is conducted to acknowledge the problems, solution potentials, and strategies that exist in current GOS as the design reference that encourages active physical activities. The research method is a qualitative method through four steps: literature studies about salutogenic five vital signs (diversity, vitality, nature, authenticity, and legacy) to identify the evaluation parameter (design criteria and indicators), 2. Research object selection, 3. Data collection through surveys, observations, and interviews, and 4. Identification and evaluation of GOS design quality. The selected research object is the GOS that potentially fulfills all salutogenic five vital signs, which is City Forest BSD I (CF I), South Tangerang. The result of the evaluation is the importance of integrating natural elements as a GOS setting because its specific character becomes the major attraction for conducting active activities. Besides, GOS needs to provide complete facilities and maintenance for all ages and activity scale from personal to communal. Generally, GOS needs to develop program and implementation strategy to develop educational and preservation activities that actively engage the community.
\end{abstract}

Keywords: sedentary, behavior, green, space, salutogenic

\section{EVALUASI RUANG TERBUKA HIJAU SEBAGAI PROMOTOR KESEHATAN DENGAN PENDEKATAN SALUTOGENIC: TAMAN KOTA BSD I SEBAGAI STUDI KASUS}

\begin{abstract}
Abstrak
Perilaku sedentary/pasif telah meningkatkan resiko terkena non-communicable disease yang menimbulkan munculnya kebutuhan untuk mendorong aktivitas fisik aktif yang dilakukan di ruang terbuka. Akan tetapi, kuantitas ruang terbuka hijau (RTH) belum memenuhi proporsi minimum 30\% dari total luas area dan kualitas desain RTH sebagai promotor aktivitas fisik aktif (kesehatan) belum memiliki referensi desain. Oleh karena itu, evaluasi desain dilakukan untuk mengetahui
\end{abstract}


permasalahan, potensi solusi, dan strategi yang terdapat pada RTH sekarang ini sebagai panduan rancang yang mendorong kegiatan fisik aktif. Metode penelitian yang digunakan adalah metode kualitatif yang dilakukan melalui empat tahap, yaitu: 1. studi pustaka mengenai lima tanda vital salutogenic (diversity, vitality, nature, authenticity, dan legacy) untuk mengidentifikasi parameter evaluasi (kriteria perancangan dan indikator desain), 2. pemilihan objek studi, 3. pengumpulan data melalui survey, observasi dan wawancara, dan 4. identifikasi dan evaluasi kualitas desain RTH. Objek studi terpilih merupakan RTH yang berpotensi memenuhi lima tanda vital salutogenic, yaitu Taman Kota BSD I (TK I), Tangerang Selatan. Hasil evaluasi RTH adalah pentingnya mengintegrasikan unsur alam sebagai setting RTH karena karakteristiknya yang spesifik menjadi daya tarik utama untuk beraktivitas aktif. Selain itu, RTH perlu menyediakan fasilitas lengkap dan pemeliharaannya untuk seluruh kategori usia dan skala aktivitas dari personal hingga komunitas. Secara keseluruhan, RTH perlu mengembangkan program dan strategi implementasi untuk mengembangkan aktivitas edukasi dan preservasi yang melibatkan komunitas secara aktif.

Kata-kata Kunci: sedentary, perilaku, ruang, hijau, salutogenic

\section{Introduction}

The modern technology which promotes more efficient works (and instant) without involving physical energy has caused sedentary occupation. It leads to 6-8 hours of working on sitting in front of a laptop or computer. Because of this routine, the study finds that $59 \%$ of office workers in Jakarta have insufficient physical activity (Abadini, 2018). Low physical activity or sedentary behavior is the type of "passive" activities that need low energy expenditure at or below 1.5 metabolic equivalents (MET) for instance sitting, working in front of the computer, playing games on the laptop, watching movies, or reading (Tremblay, 2015). These low physical energy activities relate strongly to the cultivation of fat on the body, which causes obesity and other non-communicable diseases such as cardiovascular disorder, cholesterol, diabetes, and metabolic syndrome. Furthermore, the increase of non-communicable diseases as a cause of death in Indonesia has raised the awareness from Health Ministry to combat this disease through health promotion and preventive measures through a healthy lifestyle (Faizal, 2012). Therefore, reducing the risk of sedentary behavior leads to the promotion of an active lifestyle that refers to active activities.

Active physical activity is the activity that reduces the risk of disease and death and stress (Abadini, 2018). The low physical activity, on the other hand, increases a 6-10\% possibility of being infected by non-communicable disease (Abadini, 2019). Also, active physical activity refers to running and walking in the outdoor space especially in the natural environment shows more significant improvement in mental health because it is associated with greater feelings of revitalization, positive engagement, and decreases in confusion, anger, depression, and stress (Coon, 2011). Besides, active physical activity also helps to form a sense of will and motivations through its active movement (Commisaris, 2016). Therefore, because of positivity encouragement and creation of will and motivation, active activities help to form Sense of Coherence (SOC), which is the selfsufficient mindset to overcome problems and challenges in life that give positive effects in generating mental well-being and physical health.

Consequently, active activities provide positive benefits that need outdoor space with a natural setting or green open space (GOS) to mediate this activity. However, following the rapid development of housing estate, green open space (GOS) in Jakarta and Tangerang have not yet achieved the 30\% GOS area minimum requirement: Jakarta GOS only accounts for $10 \%$, Tangerang consists of $17 \%$ (Zain, 2015), and South Tangerang accounts for 9\% (Dundu, 2011). Besides, even though Jakarta has less GOS percentage than South Tangerang, but South Tangerang has a higher rate of the increased population within seven years (Jakarta and South Tangerang Central Bureau of 
Statistics, 2016). From 2011 to 2016, the Jakarta population has increased by $1.13 \%$ (Jakarta Central Bureau of Statistics, 2016), and from 2010 to 2017, South Tangerang has increased 2,67 \% (South Tangerang Central Bureau of Statistics, 2019). Therefore, based on the high rate of increased population, South Tangerang city needs to immediately fulfill its GOS quantity requirement: a minimum of $30 \%$ of the total city area.

Along with the increased demand for GOS quantity, the development direction for the next GOS tends to be recreational parks as the strategy to cultivate the tourism potential of the South Tangerang area. Even though recreational activity provides positive benefits because it contributes to health (Gulam, 2016), but not all recreational activities are active activities. Among seven classifications of recreational activity, some recreational activities considered as light MET intensity level (1.5 - 3 MET), which is not referred to as active activities: mental and intellectual activities, art and craft activities, and hobbies. Meanwhile, the rest of the four types of recreational activities: physical activities, cultural, social activities, and outdoor activities, are considered as moderate to vigorous MET intensity levels, which refer to an active activity. Therefore, GOS that reduces the impact of sedentary behavior should provide physical, outdoor, social, and cultural activities as active activities.

The production of the activities type (active or passive) relates strongly to the design of the space because space is the setting that accommodates, generate, and shape these activities. As mentioned before, the active physical activities consist of physical (sports, outdoor) activities, social and cultural activities which show the importance of active engagement between an individual with their surroundings: physical (natural and built) environment and community. Consequently, the design of the space that promotes these activities provides the facilities (physical infrastructure) to accommodate the varied type of active activities. Moreover, space design creates a place that integrates natural settings, identity (sense of community), social capital (interactions, relations), and participation among community members to encourage active engagement within the community (Bauer, 2018). Furthermore, all these design elements have been compiled and developed by Tye Farrow as salutogenic five vitals that become the evaluation tools to identify salutogenic design quality. Therefore, the GOS that aims to be the health promoter should fulfill these five vital signs: diversity (social), vitality (social), nature, authenticity (identity), and legacy (culture).

Since GOS in South Tangerang tends to be the recreational park without further reference or guidelines on creating a salutogenic-based place, the evaluation of the recent GOS becomes pivotal. The evaluation of the recent GOS identifies current problems and potential solutions to create a space (place) that promotes well-being (active activities). Also, the evaluation determines the design strategy for the next GOS project that promotes health through active activities. Therefore, the evaluation of the recent GOS aims to provide design guidelines for the salutogenic-based GOS.

Summarily, the evaluation of GOS design quality uses the salutogenic five vital signs, which are developed as a salutogenic design evaluation tool by Tye Farrow $(2013,2018)$. These five vital signs refer to the salutogenic theory by Antonovsky, which consists of diversity, vitality, nature, authenticity, and legacy. Each vital sign consists of design criteria that are extracted to determine the salutogenic design indicator. These indicators are the parameter to identify the selected GOS (research object) design quality. The selection of the GOS itself (detailed explanation on research method section) refers to the capability of the GOS to fulfill all five vital signs. The identification of salutogenic design quality on selected GOS indicates problems that occurred on-site and determined potential solutions to create the salutogenic GOS. The last step is the evaluation of these findings to identify and determine the design strategy as salutogenic design guidelines for the next GOS. 


\section{Theoretical Framework \\ Salutogenic Theory}

The salutogenic theory is discovered by Antonovsky (1979-1994) as the thinking that focuses on promoting health rather than on disease prevention: "what causes health, rather than what causes disease." Based on Antonovsky (1979-1994), health can be achieved towards a person's capability to cope with stress. He defines this capability as a Sense of Coherence (SOC). SOC refers as selfsufficient and confident of overcoming challenges which are defined in three sense: comprehensibility, manageability, and meaningfulness. Comprehensibility means the person understands his problems as the challenges that will enhance his knowledge and experience. Next, manageability means the person's capability to overcome challenges with his skills and resources. Last, meaningfulness explains the person's will and motivation to overcome the challenges. People with strong SOC have a low-stress level that leads towards a healthy life.

Further development toward architectural health care design, as developed by Alan Dilani (2000, 2001), shows the relationship between physical elements of the built environment with mental well-being. His studies, called psychosocially responsive design, interpret 3 SOC into physical architectural elements. The orientation that influences the perceptive dimension through landmarks, nodes, movement networks, and boundary help to form the comprehensibility. Manageability, on the other hand, is applied through passive design that utilizes natural resources (natural lights) and the interior space that stimulates mental restoration through ergonomic design. Last, meaningfulness comes from activities that engage in a communal setting and through diverse forms of arts, for instance, arts, music, cultural activities that encourage positive distractions (Dilani, 2001, Ziegler, 2014). Thus, Dilani studies first show the concrete interpretation of SOC in architectural elements.

\section{Salutogenic-based Design as Design Criteria and Indicators}

Development in design from the salutary lens comes to design evaluation that is studied by Tye Farrow (2013). Their studies refer to the attachment on the emotional response towards building an environment that influences the SOC, as supported before by Dilani (2001) and Heerwagon (1995). The positive experience in architecture encourages positive emotional responses towards occupants. The positive emotional responses can be achieved through five vital signs that define the successful character of the place that promotes healthy wellbeing. These vital signs are diversity, vitality, nature, vitality, authenticity, legacy. Each of these vital signs will be explained in the sections below:

\section{Diversity and Vitality}

Diversity relates directly with vitality because diversity generates vitality. Diversity refers to the variety of activities and uses which provide the opportunity for social interactions and multicultural engagement. As mentioned by Dilani (2001), social and cultural engagement provides community support, which gives resources in overcoming the challenge of problems in a persons' life (form the SOC). These social and cultural activities create a vitality that refers to liveliness and richness of active engagement, by which the community identity is formed. Moreover, creating a place that provides diversity, and later generates vitality, relates with the essence to build a place that encourages social interactions and cultural engagement. This place should provide space that generates different kinds of activities, uses, and opens to all people, regardless of their age, gender, religion, and ethnicity (as neutral ground). Varied types of people and activities create optimal uses of the place (from morning to night), which promotes the vitality of the place. Besides, the place should provide good visual and physical permeability of the activities inside the place because people are attracted by the activities of other people (Jacob, 1961, 2011). Furthermore, the transparency of the place creates safety through the guard and supervise of other people (Jacob, 1961, 2011). Therefore, the creation of diversity and vitality develops the place that is a neutral ground with varied active activities and forms good permeability. 


\section{Nature}

Green open space links directly with physical and psychological health. In terms of physical health, nature with distinctive features becomes the attraction for people to come and use the GOS. Also, the nature setting generates specific activities that can be activated only in natural settings, for instance: boating on the river, hiking at the mountain, etc. With these opportunities, nature increases the variety of activities and uses, which enrich the diversity and strengthens vitality. Moreover, in terms of psychological health, natural setting reduces stress and distracts people from everyday life problems through stimulation of human sense: visual through colors (ex: sea and tree colors), smells (ex: smell of forest), and tactile (ex: feeling of the textures on the grass, mountains topography) (Karaca, 2018). Therefore, the activities that are engaged with nature help to create positivity through integrated nature setting and stimulation of human sense that forms SOC.

\section{Authenticity}

Authenticity refers to the acknowledgment of the local character at a particular place that forms the identity of the place itself (Ziegler, 2019). The identity of the place provides knowledge of who and what we are that create a sense of belonging to the community (community attachment). This attachment provides supports through the communal bond that acts as resources (manageability) and understanding the meaning towards the problems or challenges (meaningfulness), which help to form SOC. Therefore, the identity of the place helps to form SOC.

In design, the local character that forms the identity of the place is expressed towards distinguishing physical characteristics of the built environment that shows local symbols, meaning, and values. These distinguished local characters create a sense of familiarity that gives comforts and attachment to the people to come and use the place (Karsono, 2014). Also, local characteristics provide visual interest through its physical elements because local character resists uniformity and create the uniqueness of the place (Frampton, 1983, 2002; Kelbaugh, 2003). Besides, the physical built environment that encourages a positive response from the people indicates good accessibility and legibility. Accessibility means easy access and well-connected networks to approach the space (Karsono, 2014). Suggested connections consider walkable distance within $400 \mathrm{~m}$ from residential areas (Llewelyn-Davies, 2007). Moreover, legibility refers to the perceptual dimension of space, the creation of a mental image that makes the place to be comprehensible and comfortable. The mental image is formed by the clear movement of the place: landmark, nodes, path, and boundary (Lynch, 1960; Carmona, 2010). Thus, the place that shows authenticity through the physical built environment indicates good accessibility, legibility, and distinctive local character in their physical elements.

\section{Legacy}

Discovering meaning in life for individuals closely links with legacy (Karaca, 2018). Achieving meaning in life is earned through generativity, which means to nurture the next generations and encourage people to achieve their goals (Smith, 2017; Karaca, 2018). Meaning in life creates the will and motivation to overcome the challenges or problems in a person's life because it gives a specific purpose in life, which forms the meaningfulness of SOC. In designing the place that holds legacy as its value, a legacy comes in different kinds of perspectives: ecosystem preservation and education. Ecosystem preservation comes in terms of sustainable design that ensure the existing ecosystem is maintained for future generations. The utilization of natural resources is highly encouraged in design to minimize energy usage, especially in the utility system, to recycle and reuse waste disposal and rainwater. Besides, from educational perspectives, historical physical elements on the built environment provide traces of place transformation, knowledge about place history and cultural memory that shape the community identity. This knowledge reminds future 
generations about their community values. Also, recognizing the same ethical values bring people together as one united community, which is not only as cultural ties but also as economic survival (Oon-Seng Tan, 2017). Furthermore, learning from nature provides an opportunity for people to appreciate their essential functions and biodiversity as part of the place richness. Therefore, legacy encourages people to appreciate and acknowledge their local richness towards physical and natural elements in their built environment.

Summarily, the five vital signs: diversity, vitality, nature, authenticity, and legacy present the is design criteria for designing the place that forms SOC. Thus, salutogenic design indicator for the physical built environment interprets five vital signs that forms behavioral setting to build SOC as shown on the table below:

Table 1. Physical Built Environment as Salutogenic Design Indicator

\begin{tabular}{lll}
\hline \multicolumn{1}{c}{ Vital Sign } & \multicolumn{1}{c}{ Salutogenic Design Indicator } \\
\hline Diversity & 1. Provide varied active activities (physical, social, culture) with a specific point. \\
and Vitality & 2. Visual and physical permeability. \\
& 3. The place is neutral ground. \\
\hline Nature & 1. The place has integrated natural elements/ecosystem. \\
& 2. The place integrates activities with its natural settings. \\
& 3. The place stimulates human sense.
\end{tabular}

Authenticity Accessibility

1. The place is easily approached by multiple transportation modes and routes.

2. The place is located within a walkable distance.

3. The place has a designated public facility that is accessible and affordable.

Legibility

1. The place has a clear movement network.

2. The place has shown locality in the physical elements.

Legacy Ecosystem Conservation

1. The place puts efforts in preserving the ecosystem.

2. The place indicates designs that aim to reduce energy usage by utilizing energy resources.

Educational Purpose

1. The place has heritage buildings or physical elements that have cultural and historical backgrounds as an educational purpose.

2. The place provides knowledge to the users. Source: Author's Data, 2019

\section{Method}

The research uses the qualitative method to evaluate the GOS design based on five vital signs by Tye Farrow. First, the five vital signs are studied through literature reviews to identify the salutogenic design criteria. Then, the design criteria are extracted to identify design indicators as the evaluation tool. Consequently, the design criteria refer to Tye Farrow's five vital signs: diversity, vitality, nature, authenticity, and legacy. Diversity emphasizes a variety of activities and uses that contains multicultural and social functions. Vitality is the positive result of diversity: active activities generate liveliness of the place. Next, nature stimulates human sense through its unique characteristics which reduce stress and enrich the diversity. Other vital sign, authenticity creates an identity through the expression and embodiment of local character and value which attracts and tie people together as a community. Last, legacy refers to the continuity of personal identity through the projections of communal identity that is reserved in the form of tangible (ecosystem) and intangible 
(education) knowledge. Thus, the embodiment of five vital signs in the physical built environment creates a place that promotes health.

The second step is selecting the site that is suitable as a research object. The research object based on its capability to fulfill the five vital signs of Farrow. Based on-site observation and information gathered by articles and journals, there are six notable South Tangerang GOS that serve the functions as recreational activities, both passive and active activities: City Forest BSD I, II, Jaletreng Riverpark, Menteng Park Bintaro, Taman Perdamaian, and Taman Pamulang Permai. Among six notable GOS, City Forest III is still under construction. Consequently, among five GOS that remains, City Forest BSD I is the only GOS that potentially fulfills all salutogenic five vital signs because City Forest BSD I is the only one that potentially fulfills the last vital sign: legacy. Therefore, the selected site is CF I as the research object.

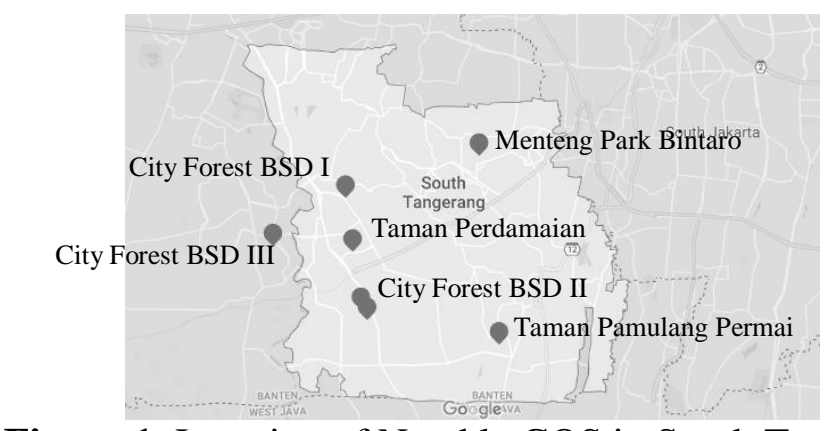

Figure 1. Location of Notable GOS in South Tangerang Source: Modified from Google Map, 2019

Thus, the selected research object is City Forest I BSD (CF I), which is a 2.5 hectare reforestation area with 60 different tree species and a total of 2,500 trees inside (Heri, 2018) and operated by South Tangerang Municipal City. CF I is located at the strategic location on the main artery road that connects the Rawabuntu Station, Jakarta Highway, and ICE (Indonesia Convention Centre). This GOS is surrounded primarily by residential and one private school, which provides an opportunity for easy access and walkable distance for residents, as shown in Figure 2 below. CF I provides space and facilities to do physical, social, and cultural activities: sports activity, sitting, chatting, picnic, and community club activities. Besides, CF I provides facilities for children and the elderly: children playground and jogging track that enhances the tactility. Also, the natural setting of CF I potentially stimulates human sense through visual (forest), sounds (birds, insects), and tactile (texture of the landscape material). Moreover, CF I also has a clear movement network and transparency for the people to see the activities from outside and inside the GOS itself. Furthermore, as the reforestation effort, CF I itself is the ecosystem preservation of the city. From the educational purpose, GOS provides knowledge for different kinds of tree species and waste recycling process which potentially fulfills the legacy vital sign. Therefore, the City Forest I BSD is selected as a suitable research object.
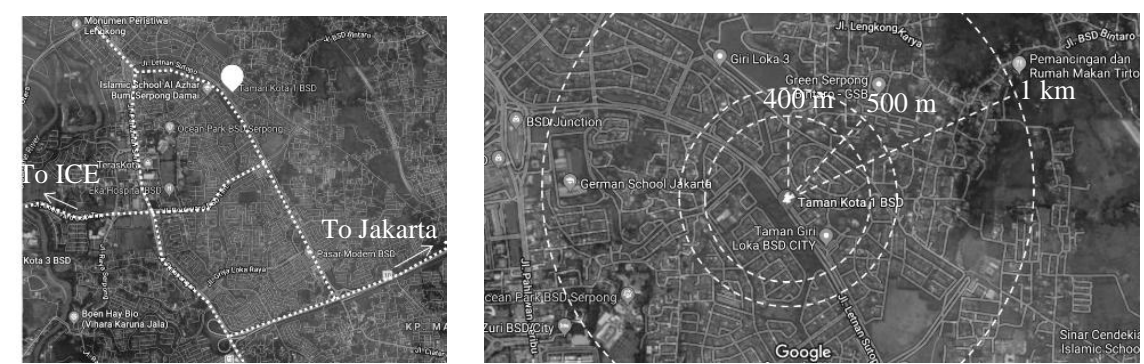

Figure 2. Macro Access of City Forest BSD (left), Micro Access (Residential Walking Distance) of City Forest BSD I (right) 
Source: Modified from Google Map, 2019

After site selection, the Five Vital Signs of the selected GOS are investigated further based on data analyses that are gathered through site surveys, observations, and user interviews. Site surveys, observations, and interviews are conducted within two months to collect data based on the reference of the salutogenic design indicator. The survey and observations aim to recognize site physical conditions and the availability of salutogenic-design elements at the selected GOS. Meanwhile, the interview selects 30 respondents: 25 visitors, two service staffs (parking), and three commercial staffs to collect data about their activity (sports, social, cultural), user's perceptions (permeability, legibility), and general satisfaction (accessibility, a preservation effort, community engagement). Consequently, the interviews use the probability sampling methods that select the respondents with the age that ranges from 15 to 65 years old to identify the varied type of activities for different ages. Besides, the respondents use a different type of transportations and their time spent to reach destinations is varied, which provide identifications on authenticity vital sign. Moreover, a different profile of the respondents conducts different activities at varied time frequencies, which provide different observations that will answer the entire aspects of five vital signs. Therefore, the site survey, observations, and interview (questions as shown at the table below) with probability sampling method provides the necessary data of GOS five vital signs.

Table 2. Interview Questions Based on Salutogenic Design Indicators

\begin{tabular}{|c|c|}
\hline $\begin{array}{l}\text { Salutogenic Design } \\
\text { Indicators }\end{array}$ & Example of Interview Questions \\
\hline \multicolumn{2}{|r|}{ Diversity and Vitality } \\
\hline $\begin{array}{l}\text { Varied activities with } \\
\text { specific locations }\end{array}$ & $\begin{array}{l}\text { - What are activities that you usually do in CF I? } \\
\text { - Where are these activities occur? }\end{array}$ \\
\hline Permeability & - Does CF I have enough transparency that shows the activities inside? \\
\hline $\begin{array}{l}\text { Universal (non- } \\
\text { segregated place) }\end{array}$ & $\begin{array}{l}\text { Do you agree that CF I is the place that opens for all people } \\
\text { regardless of their gender, religion, and ethnicity? Because.... } \\
\text { - What and where are the communal activities that occur at CF I? }\end{array}$ \\
\hline \multicolumn{2}{|r|}{ Nature } \\
\hline Natural settings & $\begin{array}{l}\text { - Does CF I have integrated nature? } \\
\text { - What are other natural elements that you expect to be provided? }\end{array}$ \\
\hline $\begin{array}{l}\text { Integrated activities } \\
\text { with nature }\end{array}$ & - Does CF I have integrated activities with nature? \\
\hline $\begin{array}{l}\text { Stimulation of human } \\
\text { senses }\end{array}$ & $\begin{array}{l}\text { - Does your sense stimulate while doing activities at CF I? If yes, for } \\
\text { example... }\end{array}$ \\
\hline \multicolumn{2}{|r|}{ Authenticity } \\
\hline Accessibility & $\begin{array}{l}\text { - How do you reach CF I and how long do you need to reach CF I? } \\
\text { - Is there any designated public transportation of CF I? }\end{array}$ \\
\hline Legibility & $\begin{array}{l}\text { - Does CF I show the local character through its physical elements? If } \\
\text { yes, please mention.... } \\
\text { - Do you experience clear orientation and easy network movement at } \\
\text { CF I? }\end{array}$ \\
\hline \multicolumn{2}{|r|}{ Legacy } \\
\hline $\begin{array}{l}\text { Ecosystem } \\
\text { preservation }\end{array}$ & $\begin{array}{l}\text { - Do you agree that CF I has provided efforts in ecosystem } \\
\text { preservation? If yes, please mention... }\end{array}$ \\
\hline
\end{tabular}


Educational purpose
- Do you think that CF I has provided the opportunity for the visitors to earn knowledge from the ecosystem or natural element at CF I?

\section{Source: Author's Interview Data, 2019}

After collecting data and gathering information, the next step is to investigate any problems or issues that occur at the site, any incongruent findings with the five vital signs, and the potential solutions regarding five vital signs at selected GOS. Later, based on these identifications, the evaluation is conducted to determine the salutogenic GOS design strategy as design guidelines for the next GOS projects.

\section{Result and Discussion Diversity and Vitality}

The City Forest BSD I (CF I) has provided facilities for different kinds of activities and uses, includes sports, social, and cultural. Based on-site survey and observations, CF I has provided sports facilities, includes jogging track, sit-up, pull, and push-up equipment. The jogging track connects all facilities that run along the periphery of the GOS, and each type of activity are collected into pods. With this design, each facility has its focal point of activities that helps the visitors to have clear spots to do their chosen activities. For social activities, the GOS has provided sitting areas (benches). For cultural activities, the GOS has provided an entrance square that is used for these activities. However, there are spontaneous sport, social, and cultural activities that are conducted at spots that do not have a clear boundary and remain scattered on the arid landscape within CF I area: picnic, playing badminton, eating, event celebration (for example Independence Day). Therefore, GOS has not yet provided clear spots for all activities which relate to the design and maintenance of the landscape inside.
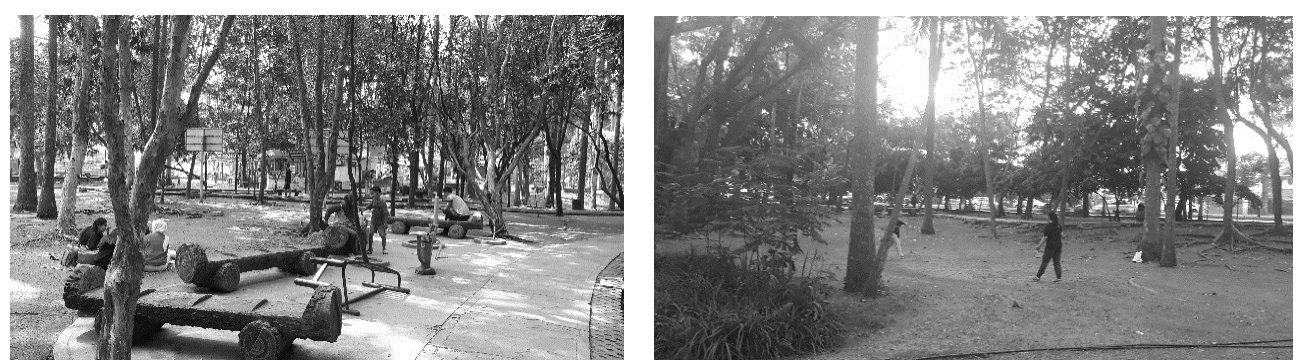

Figure 3. Activity Pod (left), playing badminton (right)

Source: Author's Documentation, 2019

Based on interviews, $60 \%$ (18 people from 30 people) stated they found the diversity of activities and uses are enough. The other $40 \%$ stated they found the GOS has not yet provided varied activities and uses because the facilities are not maintained well, which limits their choices of activities. Poor maintenance of children's facilities has stimulated the commercialized play area for children. The commercialized children play area includes children's car rental, playhouses, painting, sand-play, and target-shooting play equipment, which do not have specific spots and only available on the weekend. Also, the elderly activities are still limited both in the aspect of facilities and publication. The elderly activities are limited to a reflection track that enhances the tactile sensitivity of the elderly within the area, and the communal sports activities, for instance, tai chi, are only conducted at weekends with limited publications. Thus, the specific activity for children and the elderly is still limited, which GOS needs to improve their facilities and increase the frequency of elderly activities and publication. 

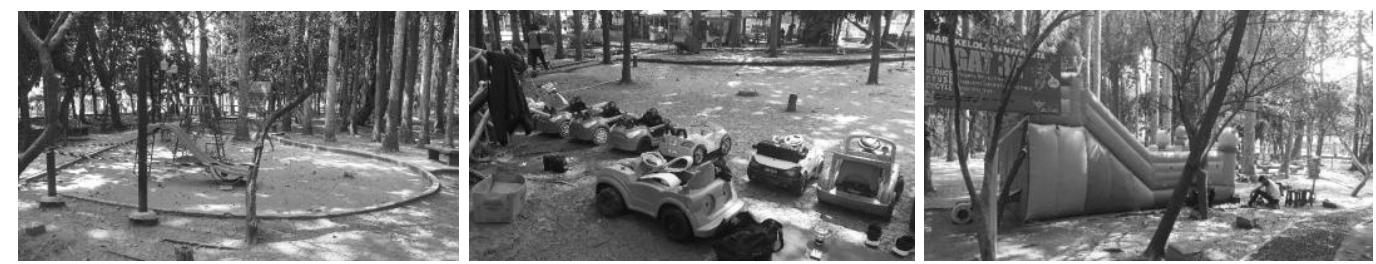

Figure 4. Unused Children Playground (left), Commercialized Children Equipment (center, right) Source: Author's Documentation, 2019

Furthermore, the most preferred activities at CF I are sports activities, with 83,33\% of respondents ( 25 people) choose to run or jog along with the jogging track (Table 1.). Social activities become the second priority when visitors come to this area, which shows chatting as the most preferred social activities, account for $16.67 \%$ (Table 1.). Other social activities include picnic/family gathering, internet, sitting, and selfie, with family gathering as the second most preferred social activity. However, cultural activities at CF I have occurred, but it has limited area and facility to provide varied cultural activities because the GOS has not yet provided space for large events, for instance, amphitheater and supported facilities storage, green room, and toilets. Besides, there are other options for these events to be conducted, for instance, shopping malls, and empty fields that provide a larger empty area for cultural event equipment that draws the public or mass of people. Thus, CF I needs to improve and maintain their main and supported facilities for enriching its diversity of activities to create vitality.

Table 3. Type of Activities

\begin{tabular}{|c|c|c|c|c|c|}
\hline Sports & $\begin{array}{c}\text { Number of } \\
\text { People }\end{array}$ & Social & $\begin{array}{c}\text { Number of } \\
\text { People }\end{array}$ & Cultural & $\begin{array}{c}\text { Number of } \\
\text { People }\end{array}$ \\
\hline Jogging & $25 / 83.33 \%$ & Chatting & $5 / 16.67 \%$ & Eating & $2 / 6.67 \%$ \\
\hline Walking & $11 / 36.67 \%$ & $\begin{array}{l}\text { Picnic/Family } \\
\text { Gathering }\end{array}$ & $3 / 10 \%$ & $\begin{array}{c}\text { Event } \\
\text { Celebration }\end{array}$ & $\begin{array}{l}\text { Varied (only on } \\
\text { the special event) }\end{array}$ \\
\hline Push-Pull Up & $6 / 20 \%$ & Internet & $3 / 10 \%$ & & \\
\hline \multirow[t]{3}{*}{ Gymnastic } & $5 / 16.67 \%$ & Social Gathering & $3 / 10 \%$ & & \\
\hline & & $\begin{array}{l}\text { Accompanying } \\
\text { Children }\end{array}$ & $2 / 6.67 \%$ & & \\
\hline & & Sitting & $2 / 6.67 \%$ & & \\
\hline
\end{tabular}

Consequently, regarding the visual and physical permeability, 83,33\% of respondents or 25 people from 30 people stated the GOS had provided permeability of activities in both visual and physical. Since the GOS selects the high height of trees and the area uses the transparent fence, the people from outside still can see the internal activities. Moreover, from inside, the majority of the usage of the high height of trees (more than three meters height of growth leaves) and transparent activity spots, the area provides visual permeability from activity point to another. Furthermore, with the jogging track that runs along the periphery, people from outside can see the activities that happen along the track. Therefore, CF I has good visual and physical permeability.

Based on interviews, 26 respondents, accounting for 86,67\%, agreed that the GOS is open for any different ages, gender, religion, and ethnicity. They mentioned that they could see the sharedactivities that occur along the jogging track, activity pods, and another spontaneous picnic area. Also, they do not find any problems that occur during their visits between different kinds of ages, gender, religion, or ethnicity. The rest of the respondents account for four people out from 30 people mentioned the place has not yet given welcoming gestures because of the limited cultural events that 
can gather all people. Thus, CF I has provided opportunities for all people to come and do the activities, but still needs to provide varied cultural activities to build community ties.

Summarily, CF I has fulfilled the whole 3 points of diversity and vitality with limitations on cultural activities, elderly, and children's activities. The three points are: GOS has provided a different kind of activities, it has visual and physical permeability, and perform as universal place, as can be seen through the diagram below. Thus, the next development needs to improve and add facilities, especially on children and elderly-related activities, and cultural activities.

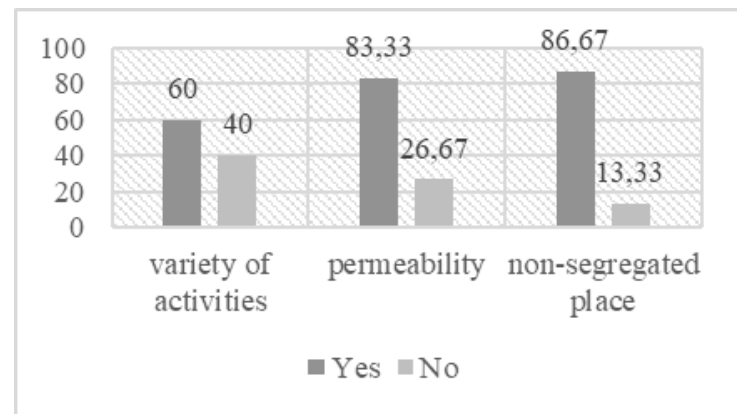

Figure 5. Salutogenic Design Indicator in Diversity and Vitality Criteria (Percent) Source: User Interview, 2019

\section{Nature}

CF I is the GOS that has the forest as their natural setting to be the lung of the city. However, the natural setting has not yet integrated fully with the activities within. Approximately half of the respondents account for 56,67 \% mentioned they have not yet found any integrated activities with the forest setting and expect to have a more natural ecosystem to be integrated with the GOS. The highest preference of the natural ecosystem that expected to be added is river and grassland, which each account for $23.33 \%$. Expectations on grasslands include flower gardens and grass addition derive from the dull and arid landscape at GOS, and the water elements are expected to be added because the water element encourages children-related activities, especially water features as a playground. Even though the GOS has not yet achieved the maximum potential of its natural setting and integrated activities, $76,67 \%$ or 23 people found their sense are stimulated through the view of trees, sounds of birds and bugs, and comfortable shades of trees that create a tranquil atmosphere. Moreover, they also found that they feel relaxed during the visits, which becomes their reason to visit the place. Furthermore, $96.67 \%$ of respondents found the place is attractive because of its positive nature effect: cool temperatures because of tree shades and tranquility. Therefore, the CF I with its forest settings has become the major attractions for people to come, but still need to increase integrated activities with landscape improvement and addition of water elements. Summarily, the CF I has fulfilled 2 out of 3 indicators of nature design criteria: CF I has a natural setting that stimulates the human sense, but need to be integrated with nature-specific activities. Potential development is adding water elements and improving the landscape. 


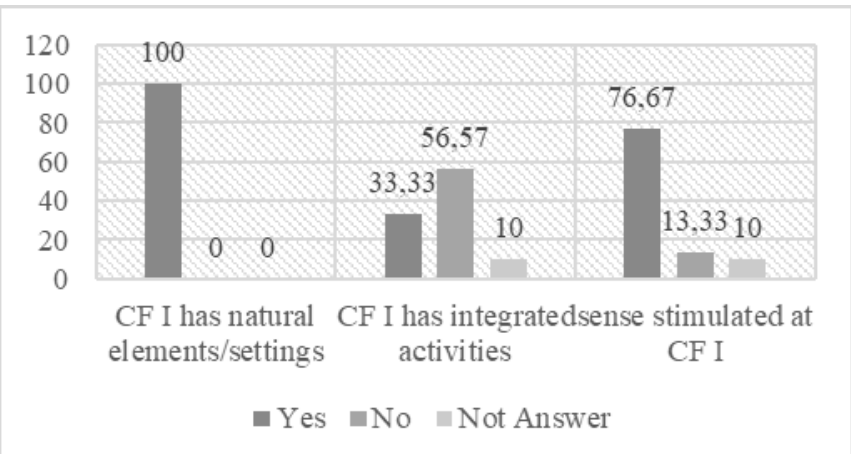

Figure 6. Salutogenic Design Indicator in Nature Criteria (Percent)

Source: User Interview, 2019

\section{Authenticity}

Regarding authenticity, the place is assessed by two criteria: accessibility and legibility. Based on accessibility, 96,67\% of respondents stated CF I is easily accessed by different kinds of transportations even though the length of time is varied from 10 minutes to 2 hours by motorcycle or online transportation, 30 minutes by foot, and 30 minutes to one hour by private car. The variety of time shows that the distance between CF I and their residentials are not walkable. Since the CF I is located along the primary road that links directly to the main artery road with clear entrance, the location is easily recognized and approached by visitors. However, the place has not yet provided specific public transportation that links between city nodes and CF I, which causes the visitors to use their vehicle or online transportations. Furthermore, based on legibility, $66.67 \%$ of respondents or 20 people from 30 people stated they have a clear orientation about the place even though the place has not yet provided distinctive local character through its physical elements of the built environment. They also think that the active activities inside GOS do not need to have a local character. Moreover, movement network: path (jogging track) and landmark (main entrance square) have provided clear orientation for visitors. The main entrance square is located in the middle of the area which is surrounded by taverns and food stalls that connect pathway (jogging track) that runs along the periphery of the GOS. Therefore, based on accessibility and legibility, CF I have fulfilled each one indicator from two criteria: the place is easily accessed by different types of transportation mode and has clear orientations within the area, which is shown at the diagram below:
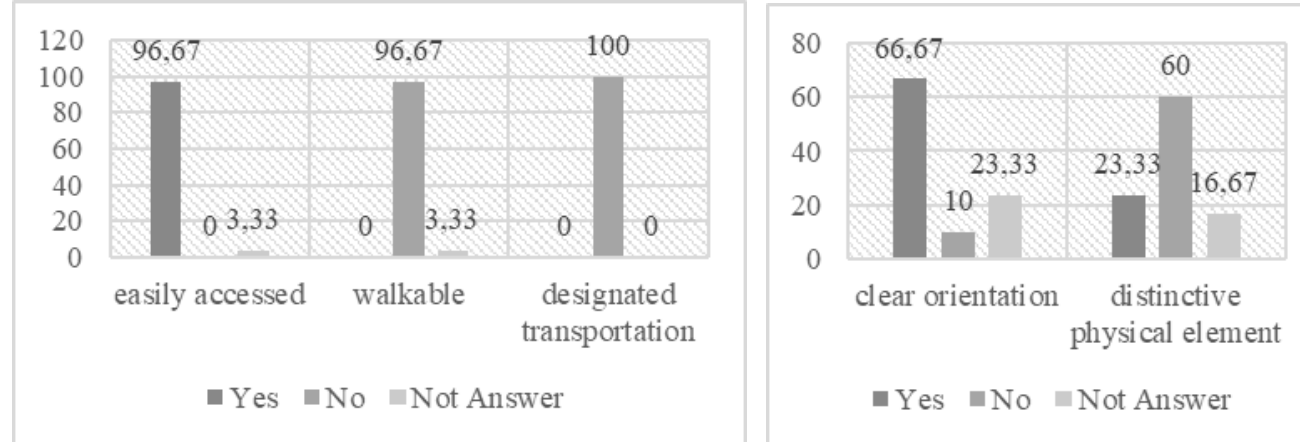

Figure 7. Salutogenic Design Indicator in Authenticity Criteria Source: User Interview, 2019

\section{Legacy}

The last vital sign is a legacy, which is assessed through two criteria: sustainability and educational purpose. From the aspect of sustainability, 63,33\% of respondents recognize that GOS is the reforestation effort to be the lung of the city, which considers one of the efforts to sustain the ecosystem. However, the efforts to maintain the ecosystem have not yet further developed in other 
forms. 53,33\% of respondents or 16 people from 30 people stated that CF I has not yet provided a design that specifically aims to reduce the energy usage. Moreover, only 14 people or 46,67\% found that the waste recycle system is enough for its sorting effort. However, the other nine respondents have not yet found the waste sorting process only is enough. Furthermore, from the educational perspective, the GOS do not have any cultural and historical buildings or other physical built environment within the area. However, the GOS has put efforts to provide knowledge by utilizing its forest setting: recognizing tree names and species, but the conditions of the signage quality are poor, and the quantity of the signage and trees themselves have been reduced. Summarily, CF I has fulfilled only one design indicator of legacy, which is ecosystem preservation.
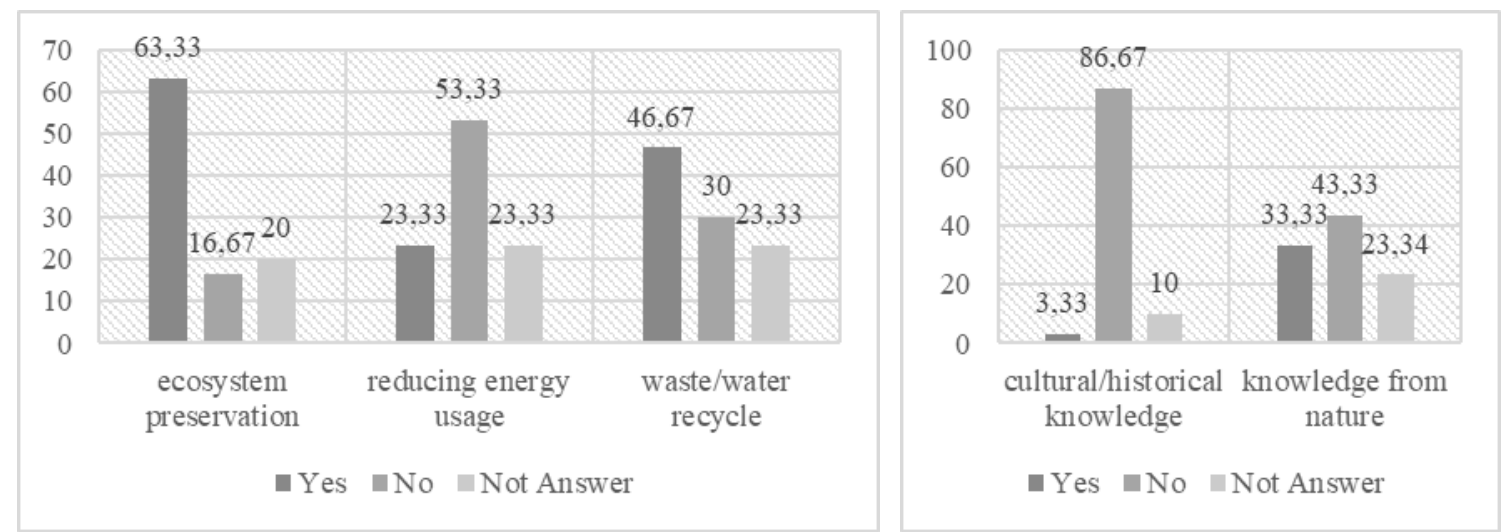

Figure 8. Salutogenic Design Indicator in Legacy Criteria (In Percent)

Source: User Interview, 2019
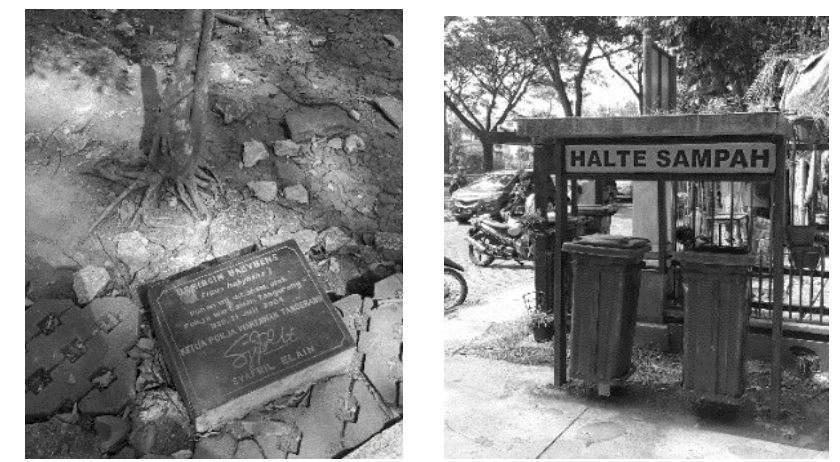

Figure 9. Tree Name and Species Signage (left and middle), Waste Sorting Disposal (right)

Source: Author's Documentation, 2019

Overall, the City Forest BSD I has fulfilled all three indicators of diversity and vitality signs, but with limitations on children and elderly-related activities and needs to provide facilities for large scale of cultural activities. In terms of nature, the GOS has fulfilled 2 out of 3 indicators, which need to integrate nature-based activities. Consequently, CF I only fulfilled one out of 3 indicators for accessibility and one out of 2 indicators for legibility, which shows the need to provide designated public transportation and integrate local characters within the area. Last, in the term of legacy, the GOS has fulfilled only one out of 3 indicators for sustainable preservation and one out of two indicators for the educational purpose which show the need for the GOS to improve its facilities and develop a rigorous program for preservation and educations that actively engage with the community. Therefore, from a total of 16 indicators of salutogenic design, CF I only fulfill approximately eight indicators out of 16 indicators with two indicators remain limited: limitation on cultural, children, elderly-specific activities, and educational purpose. 
Summarily, the salutogenic evaluation of selected GOS provides design considerations on the next GOS projects. First, GOS integrates nature as the setting because its distinctive feature becomes the major attraction. Nature provides more varied activities for the people because some activities can be done only in a natural setting, and the effect of trees shade creates a cool and relaxing atmosphere. The GOS also needs to encompass all sports, social, and cultural activities that are accessible for children, adults, and the elderly. Next, for easy access, the location of the GOS should be located at strategic locations that are easily approached by a different type of transportation modes and routes. Visitors do not concern with the 15 minutes walking distance and prefer the availability of designated public transportations that links the city nodes to CF I. Even though CF I do not have the distinctive local character in their physical built element, but legibility can be achieved through clear movement networks and specific spots or pods of activities. Last, nature has potential as knowledge providers that make people appreciate and acknowledge their local richness with the need to maintain and improve facilities. Thus, nature as the driver for GOS active activities should be supported by good facilities and develop a nature-related preservation program for active community engagement.

\section{Conclusion}

Based on the evaluation of five vital signs design criteria, City Forest I BSD, a salutogenic GOS should integrate nature as the setting because nature is the major attraction for people to come. The people themselves, even without a good quality of facilities will produce spontaneously a variety of activities that potentially create vitality of GOS. Besides, GOS should provide varied active activities for all people. Moreover, GOS should have good accessibility, permeability, and legibility through clear movement networks, space transparency, and designated infrastructure. Furthermore, not only the maintenance of facilities but GOS needs to form the designated program and implementation strategy to strengthen its legacy-purposed activities that engage the entire community. Therefore, the Salutogenic-based design of GOS is the universal place for all people that integrate both physical and psychological aspects of the place itself to form self-resourcefulness and community empowerment.

\section{References}

Abadini, D., and Wuryaningsih, Caroline E. (2019). Determinan Aktivitas Fisik Orang Dewasa Pekerja Kantoran di Jakarta Tahun 2018. Jurnal Promosi Kesehatan Indonesia Vol.14 No.1: 15-28.

Bauer, George F. (2017). The Application of Salutogenesis in Everyday Settings. In The Handbook of Salutogenesis. Switzerland: Springer International Publishing

Bergstrom, M., Hansson, K., Lundblad, A-M., \& Cederblad, M. (2006). Sense of Coherence: definition and explanation. International Journal of Social Welfare, 15(3), 219-229.

Carmona, M, et all. (2010). Public places, urban spaces: the dimensions of urban design. Amsterdam: Elsevier

Commissaris, D., et al. (2016). Interventions to Reduce Sedentary Behavior and Increase Physical Activity during Productive Work: A Systematic Review. Scandinavian Journal of Work, Environment \& Health, vol. 42, no. 3: 181-191

Coon, JT., et all. (2011). Does Participating in Physical Activity in Outdoor Natural Environments Have a Greater Effect on Physical and Mental Wellbeing than Physical Activity Indoors? A Systematic Review. Environment Science and Technology, Vol. 45 No. 5: $1761-1772$
Dilani, A. (2001). Psychosocial Supportive Design Scandinavian Healthcare Design. Alan Dilani Design and Health - Therapeutic Benefits of Design: 31-38

Dundu, Pingkan E. (2011). Tangsel Minim Ruang Terbuka Hijau. Retrieved from: https://properti.kompas.com/read/2011/10/25/2124152 6/tangsel.minim.ruang.terbuka.hijau

Faizal, Elly B. (2012). Indonesia Announces Wide-Ranging Actions to Address Non-Communicable Disease. Retrieved from https://ncdalliance.org/es/newsevents/news/indonesia-announces-wide-rangingactions-to-address-non-communicable-diseases

Farrow, T. (2013, October). Designed to Thrive: Creating Salutogenic Environment. Presented at Architectural Institute of British Columbia's (AIBC) Annual Conference, Vancouver, Canada.

Farrow, T. (2018). The Ultimate Test for Design: Does It Cause Health. In Health Environments, Healing Spaces: Practices and Directions in Health, Planning, and Design. US: University of Virgina Press

Frampton, K. (2002). Towards Critical Regionalism: Six Points for an Architecture of Resistance. In Labour, Work, and Architecture. NY: Phaidon Press

Gulam, A. (2016). Recreation - Need and Importance in Modern Society. International Journal of Psychology, 
Nutrition, and Physical Education Vol 1. No. 2: 157160

Harrington, J. (1991). Work-Related Disease And Injuries. BMJ: British Medical Journal, 303(6807), 908-910.

Heerwagon, J., Janet, H., Joseph, M., and Wally, W. (1995). Environmental Design, Work, and Well Being: Managing Occupational Stress Through Changes in the Workplace Environment.Workplace Health \& Safety (formerly AAOHN Journal) Vol. 43 No. 5: 458-68.

Heri, W. (2018, May 11). Taman Kota 1 Sebagai Paru-paru Tangerang. Retrived from: https://www.bacatangerang.com/taman-kota-1sebagai-paru-paru-tangerang/

Jacobs, J. (2011). The Death and Life of American Cities (50 ${ }^{\text {th }}$ ed.). New York: Random House

Jakarta Central Statistic of Bureau. (2019). Jumlah Penduduk Kota Jakarta, 2010-2015. Retrieved from: https://jakarta.bps.go.id/statictable/2017/01/30/136/ju mlah-penduduk-dan-laju-pertumbuhan-pendudukmenurut-kabupaten-kota-di-provinsi-dki-jakarta-20102014-dan-2015.html

Karaca, E. (2018). Salutogenic Approach for Designing Restorative Environments. The Journal of Academic Social Science, 6 (67), 116-131.

Karsono, B., and Wahid, J. (2015). Attributes and Characteristics of Place Attachment. Applied Mechanics and Materials, Vol. 747: 132-135.

Kelbaugh, D. (2017). Repairing the American Metropolis: Common Place Revisited. [S.I.]: Univ of Washington Press

Llewelyn-Davies (Firm), Alan Baxter \& Associates., English Partnerships., \& Housing Corporation. (2007). Urban Design Compendium: English Partnerships, the Housing Corporation. London: English Partnerships.

Lynch, K. (1960). The Image of the City. Cambridge, Mass.: MIT Press

Mittelmark, Maurice B., et all. (2017). The Handbook of Salutogenesis. Switzerland: Springer International Publishing
Niedermeier, M, et al. (2017). Affective Responses in Mountain Hiking-A Randomized Crossover Trial Focusing on Differences between Indoor and Outdoor Activity. Public Library of Science Vol. 12, no. 5: 117.

Oon-Seng Tan, Ee-Ling Low, and Hung, D. (2017). Lew Kuan Yew's Educational Legacy: The Challenges of Success. Singapore: Springer Nature Singapore Pte Ltd

Smith, Emily E. (2017). Psychology shows it's a big mistake to base our self-worth on our professional achievement. Retrieved from https://qz.com/990163/psychology-shows-its-a-bigmistake-to-base-our-self-worth-on-our-professionalachievements/

South Tangerang Central Statistic of Bureau. (2019). Jumlah Penduduk Kota Tangerang Selatan, 2010-2017. Retrieved from: https://tangselkota.bps.go.id/dynamictable/2017/05/09 /49/jumlah-penduduk-kota-tangerang-selatan-20102017.html

Tremblay, Mark S., et all. (2017). Sedentary Behavior Research Network (SRBN) - Terminology Consensus, Project Process, and Outcome. International Journal of Behavioral Nutrition and Physical Activity 14:17

Vinje, Hege F., Langeland, E., and Bull, T. (2017). Aaron Antonovsky's Development of Salutogenesis, 1979-1994. In The Handbook of Salutogenesis (pp. 25-40). Switzerland: Springer International Publishing AG

Zain, Alinda FM., et all. (2015). The Detection of Urban Open Space at Jakarta, Bogor, Depok, and Tangerang - Indonesia by Using Remote Sensing Technique for Urban Ecology Analysis. Proceedia Environmental Science 24: 87-94.

Ziegler, E. (2014). Application of a Salutogenic Design Model to the Architecture of Low-Income Housing (Master Thesis). Retrieved from: https://open.library.ubc.ca/cIRcle/collections/ubcthese s/24/items/1.0135612 